ВДОСКОНАЛЕННЯ СПОСОБІВ ВИКОНАННЯ ЗАХИСТІВ ЛІНІЙ

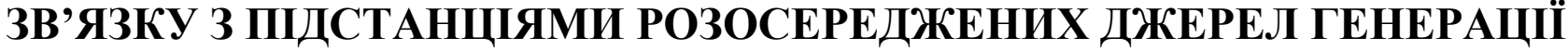

\author{
А. О. Омельчук, кандидат технічних наук, доцент \\ С. М. Волочин, кандидат технічних наук, доцент \\ O. I. Тарасюк, аспірант
}

\begin{abstract}
Національний університет біоресурсів і природокористування Украӥни
E-mail: semvenergy@gmail.com
\end{abstract}

\begin{abstract}
Анотація. Розглянуті проблеми використання релейного захисту для ліній електропостачання. Звернуто увагу на особливості роботи захисту при різних режимах роботи цих ліній, а саме: нормальному, післяаварійному та плановоремонтному. Захист ліній з двостороннім живленням, які зв'язують з потужними електричними системами окремі місцеві електростанції, в тому числі розосереджені джерела генерачіï, місиеві системи $i$ розосереджені джерела генераиії між собою, повинні задовольняти загальні вимоги забезпечення необхідної чутливості, селективності дії при різних видах пошкоджень. Труднощі в забезпеченні необхідної чутливості при використанні максимальних струмових захистів на таких лініях пов'язані з малим рівнем струмів короткого замикання від розосереджених джерел генерації і місиевих електричних систем. Наведено особливості виконання релейного захисту при резервуванні електропостачання споживачів з використанням розосереджених джерел генераџії. Максимальний робочий струм лінії, котрий споживається з електричної системи, в 2 - 3 рази перевищує номінальний струм, який визначається потужністю генераторів розосереджених джерел генерації. При изьому струми короткого замикання від генераторів малопотужних розосереджених джерел генерації виявляються співрозмірними з максимальними робочими струмами лінії. На лініях 3 двостороннім живленням, які зв'язують з потужною електричною системою місиеві системи і розосереджені джерела генеращії між собою, максимальні струмові направлені захисти забезпечують селективність $і$ є основними видами захистів таких ліній.
\end{abstract}

Ключові слова: електропостачання, релейний захист, реклоузери, секціонолайзери, розосереджені джерела генерації, коротке замикання, секціонування, селективність

Актуальність. Розподільчі мережі 3 розосередженим електричним навантаженням представляють собою розгалужені повітряні радіальні лінії напругою 10 кВ, виконані проводами різних марок і перерізів.

3 розвитком мережевого резервування такі мережі отримують секціонування 
та резервування шляхом спорудження перемичок, обладнаних пунктами автоматичного вмикання резерву (ABP) між лініями, які живляться від різних районних підстанцій 35...110/10 кВ (рис. 1).

Аналіз останніх досліджень та публікацій. Як секціонуючі апарати застосовуються:

1) вакуумні реклоузери з системою контролю і захисту приєднань;

2) віддільники для автоматичного виділення пошкодженої ділянки в безструмову паузу 3 подальшим автоматичним вмиканням непошкодженої частини лінії;

3) вимикачі навантаження стовпові з повітряною та елегазовою ізоляцією;

4) автоматичні лінійні секціонолайзери - перспективними комутаційні апарати, які не мають в своєму складі пристроїв релейного захисту і автоматики i не призначені для відключення струмів короткого замикання;

5) ефективним доповненням роботи наведених пристроїв можуть слугувати запобіжники-роз'єднувачі вихлопного типу зовнішнього розміщення.

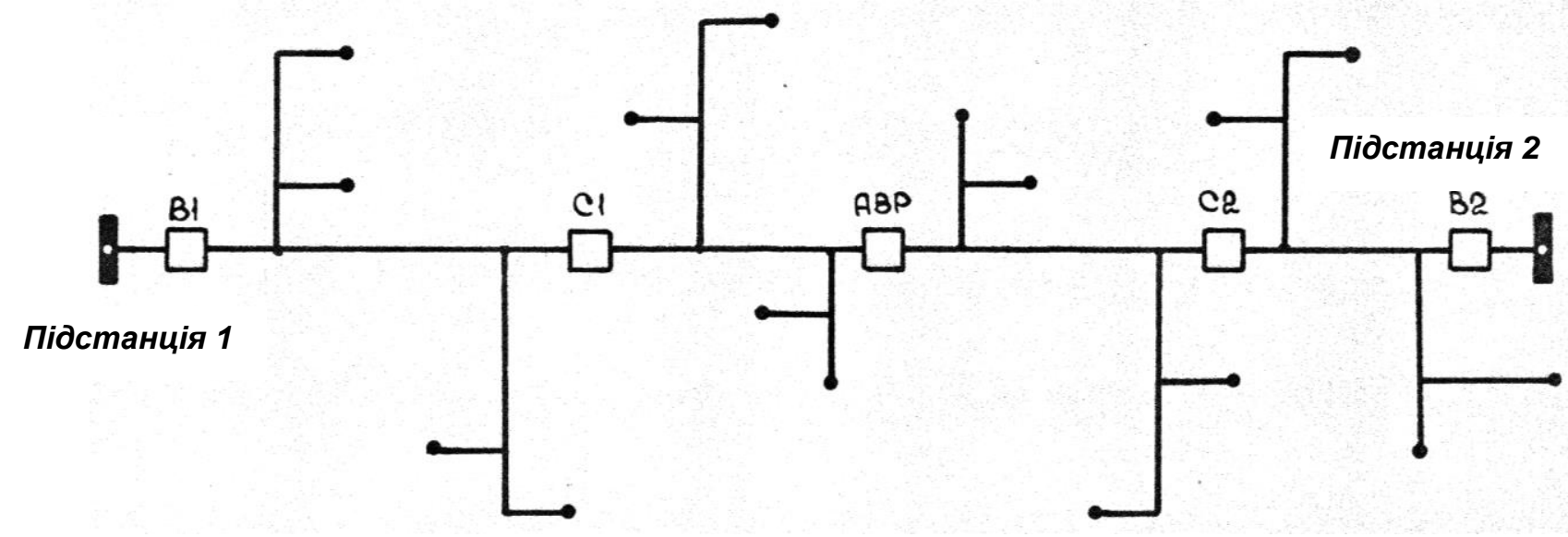

Рис. 1. Схема секціонування лінії 10 кВ з АВР:

- - підстанції 10/0,4 кВ; C1, С2 - пункти секціонування; АВР - пункт автоматичного вмикання резерву; В1, В2 - вимикачі головних ділянок лінії

3 точки зору можливості виконання чутливого, селективного захисту розподільчих мереж, надійності роботи приводу, зручності експлуатації кращим рішенням $є$ використання реклоузерів та інших наведених комутаційних пристроїв [1].

Мета дослідження - обгрунтувати найдоцільніші способи виконання захисту 
i автоматики ліній електропостачання 3 розосередженим електричним навантаженням.

Матеріали і методи дослідження. Лінії 3 мережевим резервуванням в нормальному режимі, який є основним за тривалістю, працюють з розімкненим пунктом АВР. При виникненні короткого замикання відключається пошкоджена ділянка лінії, а непошкоджена автоматично підключається до другого джерела живлення. Можливі також планові відключення лінії з підключенням їі пунктом АВР до лінії, яка живиться від другої підстанції. Таким чином, ці лінії можуть працювати в таких режимах (рис. 2): нормальному (I) і післяаварійному або планово-ремонтному, коли обидві лінії, зв'язані пунктом АВР, отримують живлення від однієї або другої підстанції (II, III).

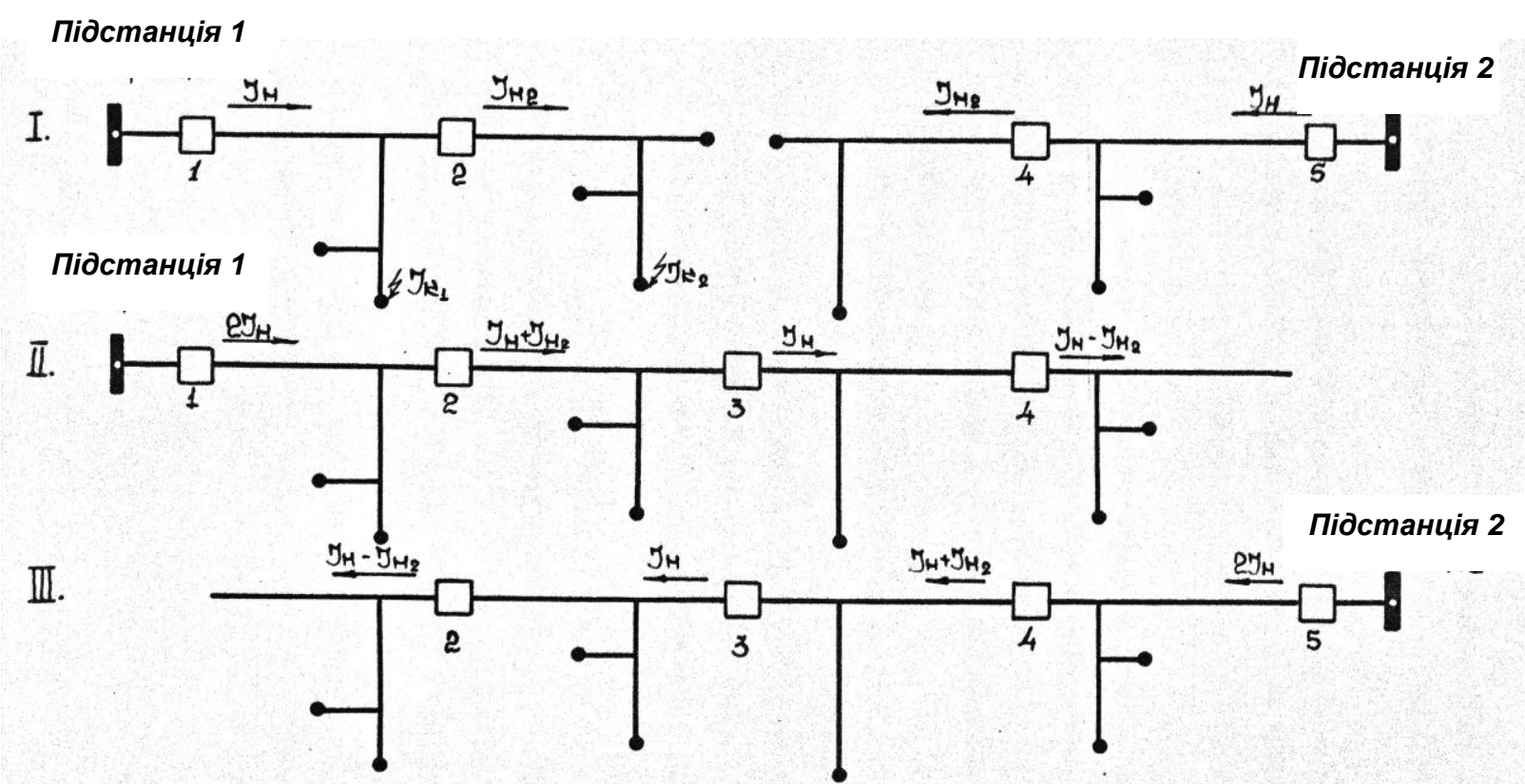

Рис. 2. Режими роботи секціонованої лінії з мережевим резервуванням:

1, 5 - вимикачі головних ділянок; 2, 4 - секціонуючи вимикачі; 3 - пункт АВР

Вказані режими відрізняються:

- величиною і направленням розрахункового струму навантаження, від якого потрібно відлагоджувати роботу пристроїв захисту;

- величиною і направленням струмів короткого замикання, при виникненні яких необхідно забезпечити чутливу і селективну роботу пристроїв захисту.

Це і ускладнює виконання захисту секціонованих розподільчих ліній 3 
мережевим резервуванням, а саме:

а) необхідність відлагодження захисту від максимального розрахункового струму навантаження при включеному пункті АВР, що призводить до «загублення» його навіть в нормальному режимі живлення лінії (при відключеному пункті АВР);

б) зменшення величин струмів короткого замикання при виникненні пошкодження в найбільш віддалених точках при живленні обох ліній, з'єднаних пунктом АВР, від однієї з підстанцій, що знижує надійність роботи захисту в умовах малих запасів по коефіцієнту чутливості;

в) необхідність забезпечення селективної роботи захистів в різних режимах роботи ліній при зміні віддаленості місць встановлення захистів (пунктів секціонування і АВР) від джерел живлення, що призводить до необхідності застосування на розглядуваних лініях захистів, аналогічних захистам ліній, працюючих з нормально ввімкненим пунктом АВР.

Другим видом резервування електропостачання споживачів є використання розосереджених (місцевих) джерел генерації (РДГ): малих гідроелектростанцій, вітрових та сонячних електростанцій, теплових електростанцій підприємств тощо. Лінії, які зв’язують ці РДГ з підстанціями, зазвичай являють собою лінії без відгалужень і виконані на напругу 35 кВ або 10 кВ. На відміну від ліній з мережевим резервуванням лінії зв'язку РДГ і системи 3 підстанціями, які живляться від потужних енергосистем, працюють в нормальному режимі як лінії 3 двостороннім живленням. По них здійснюється передавання потужності від підстанції споживачам, приєднаним до шин РДГ. При використанні потужності РДГ в нормальному режимі або при виникненні аварійних режимів в системі і відключенні ліній зв'язку РДГ забезпечують електропостачання споживачів (в першу чергу - найбільш відповідальних).

Загальною вимогою до захисту цих ліній $є$ забезпечення чутливості i селективної роботи при пошкодженнях в різних точках схеми електропостачання. Максимальний робочий струм, що передається по лінії зв’язку від потужних електросистем до шин РДГ, значно перевищує номінальний струм, який визначається потужністю РДГ. У той же час струми короткого замикання від РДГ 
обмежені через значний реактивний опір генераторів малої і середньої потужності (рис. 3) і можуть бути співставні з максимальним робочим струмом ліній. Це ускладнює забезпечення необхідної чутливості захисту на таких лініях.

Результати досліджень та їх обговорення. 3 виконанням резервування електропостачання розосереджених споживачів пов'язане ускладнення роботи релейного захисту розподільчих ліній 10 кВ. Тому для успішного широкого впровадження i ефективного використання РДГ необхідно обгрунтувати найбільш доцільні способи виконання захисту і автоматики ліній цього класу.
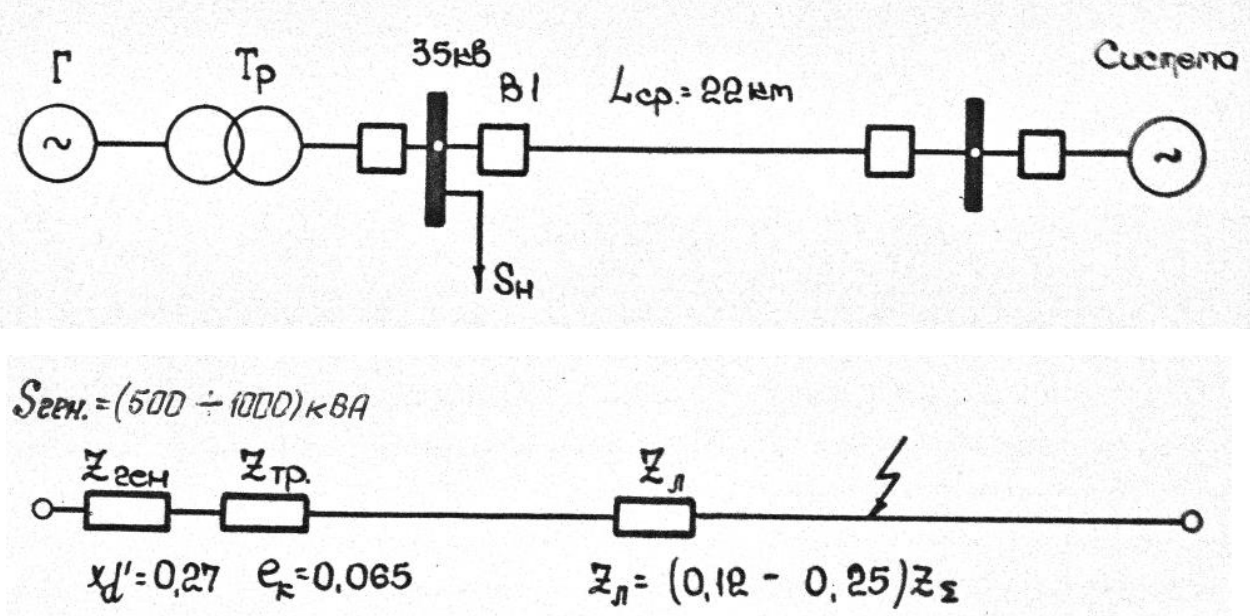

\section{Рис. 3. Принципова схема і схема заміщення РДГ, зв'язаного з електричною системою}

Захист ліній 3 двостороннім живленням, які зв'язують 3 потужними електричними системами окремі місцеві електростанції, в тому числі РДГ, місцеві системи і РДГ між собою, повинні задовольняти загальні вимоги забезпечення необхідної чутливості, селективності дії при різних видах пошкоджень. Труднощі в забезпеченні необхідної чутливості при використанні максимальних струмових захистів на таких лініях пов'язані з малим рівнем струмів короткого замикання від РДГ і місцевих електричних систем.

При середніх параметрах РДГ і ліній зв'язку, а саме відносного реактивного опору генераторів $\searrow_{\mathrm{d}}=0,27$ в.о., $\mathrm{S}_{\text {ген }}=1000$ кВА, трансформатора $\mathrm{x}_{\text {тр.* }}=0,065$ в.о., довжині лінії зв'язку, виконаної проводом АС-50 - 25 км - відносна величина сталого значення струму трифазного короткого замикання при пошкодженні в 
кінці лінії складає 2,3· $\mathrm{I}_{\mathrm{H}}$ (де $\mathrm{I}_{\mathrm{H}}$ - номінальне значення струму в лінії, яке визначається потужністю генератора).

Для забезпечення коефіцієнта чутливості $K_{4}=1,5$ необхідно, щоб величина струму трифазного короткого замикання в кінці ділянки лінії, яка захищається, складала:

$$
I_{\kappa .3 .}^{(3)}=\frac{2}{\sqrt{3}} \cdot K_{u} \cdot I_{c .3 .}=\frac{2 \cdot K_{u}}{\sqrt{3} \cdot K_{\text {пов }}} \cdot K_{\psi} \cdot I_{\text {p.макс., }}
$$

де $\mathrm{I}_{\text {р.макс }}$ - максимальне значення робочого струму лінії, А.

При виконанні захисту на реле непрямої дії ця величина складає:

$$
I_{\kappa .3 .}^{(3)}=2,6 \cdot I_{\text {р.макс., }}
$$

Максимальний робочий струм лінії, який споживається 3 електричної системи, в 2 - 3 рази перевищує номінальний струм, який визначається потужністю генераторів РДГ. При цьому струми короткого замикання від генераторів малопотужних РДГ виявляються співрозмірними 3 максимальними робочими струмами лінії.

На лініях з двостороннім живленням, які зв'язують з потужною електричною системою місцеві системи і РДГ між собою, максимальні струмові направлені захисти забезпечують селективність іє основними видами захистів таких ліній.

До недоліків цих захистів відноситься наявність «зони нечутливості» при близьких коротких замиканнях. Величина незахищеної ділянки лінії визначається за виразом:

$$
\begin{aligned}
& l_{x}=\frac{n_{u} \cdot n_{T}}{\sqrt{3} \cdot Z_{J}} \cdot \frac{S_{c p . \text { мiн }}}{\left(I_{\kappa .3 .}^{(3)}\right)^{2} \cdot \cos \left(\varphi_{p}+\alpha\right)}= \\
& =\frac{n_{u}}{\sqrt{3} \cdot I_{u}^{2} \cdot Z_{1} \cdot \cos \left(\varphi_{p}+\alpha\right)} \cdot \frac{S_{c p . \text { мi }}}{n_{T} \cdot \kappa^{2}},
\end{aligned}
$$

де $\mathrm{Z}_{1}$ - питомий опір прямої послідовності лінії, Ом/км; $\varphi_{\mathrm{p}}$ - кут між векторами струму і напруги, яка підводиться; $\alpha$ - додатковий кут, що визначається типом реле; $\mathrm{n}_{\mathrm{H}}, \mathrm{n}_{\mathrm{T}}$ - коефіцієнти трансформації трансформаторів напруги і струму; $\mathrm{S}_{\mathrm{cp} .}-$ потужність спрацювання реле, ВА; к - кратність струму короткого замикання по 
відношенню до номінального струму лінії; $\mathrm{I}_{\text {к.3. }}{ }^{(3)}$ - значення струму трифазного короткого замикання, А.

При $\mathrm{n}_{\mathrm{H}}=350$ i $\mathrm{I}_{\mathrm{H}}=5 \mathrm{~A}$

$$
l_{x}=\frac{8,1}{Z_{1} \cdot \cos \left(\varphi_{p}+\alpha\right)} \cdot \frac{S_{c p . \text { мiн }}}{n_{T} \cdot \kappa^{2}} .
$$

Аналіз залежності величини «зони нечутливості» від кратності струмів короткого замикання при різних марках проводів і величини навантаження ліній показує, що величина «зони нечутливості» в середньому складає 3 - 4 км, тобто до $15 \%$ довжини лінії. Але ймовірність трифазного короткого замикання, при яких може виникнути пошкодження в «зоні нечутливості», не перевищує 5 \% загального числа пошкоджень.

Висновки і перспективи. Для відключення близьких до місця встановлення захисту коротких замикань використовуються струмові відсічки. При застосуванні струмових відсічок на лініях з двохстороннім живленням більше 50 \% довжини лінії залишається незахищеною. Це пов'язано з відносно малою зміною струму короткого замикання вздовж лінії, оскільки відносна величина повного опору лінії в загальному опорі схеми заміщення складає $12 \ldots 25 \%$ (рис. 3). У поєднанні з максимальними струмовими направленими захистами струмові відсічки доцільно використовувати для надійного відключення близьких коротких замикань.

У тих випадках, коли максимальні струмові направлені захисти не забезпечують необхідної чутливості, на розглянутих лініях також як і на лініях 3 мережевим резервуванням, доцільно використовувати дистанційні захисти 3 залежною витримкою часу. Підвищення чутливості захисту при цьому обумовлено значним зниженням напруги на шинах РДГ при зовнішніх коротких замиканнях через відносно великий реактивний опір генераторів малої і середньої потужності.

\section{Список літератури}

1. Шабад М.А. Расчеты релейной защиты и автоматики распределительных сетей: Монография 4-е изд., перераб. и доп.. СПб.: ПЭИПК, 2003. 350 с. 
2. Резниченко Т. Ф., Омельчук А. О., Козырский В. В. О расчете зоны защиты токовой отсечки. Энергетика и электрификация. 1994. №4. С.43-44.

\section{References}

1. Shabad, M. A. (2003) Raschety releynoy zashchity i avtomatiki raspredelitel'nykh setey: Monografiya [Calculations of relay protection and automation of distribution networks: Monograph]. SPb.: PEIPK, 350.

2. Reznichenko, T. F., Omel'chuk, A. O., Kozyrskiy, V. V. (1994). O raschete zony zashchity tokovoy otsechki [On the calculation of the current cutoff protection zone]. Energetika i elektrifikatsiya, 4, 43-44.

\section{УСОВЕРШЕНСТВОВАНИЕ СПОСОБОВ ВИПОЛНЕНИЯ ЗАЩИТ ЛИНИЙ СВЯЗИ С ПОДСТАНЦИЯМИ РАССРЕДОТОЧЕНЫХ ИСТОЧНИКОВ ГЕНЕРАЦИИ}

\section{А. А. Омельчук, С. М. Волошин, О. И. Тарасюк}

Аннотация. Рассмотрена проблема использования релейной защзитьл линий электроснабжения. Обращено внимание на особенности работы защиты при различных режимах работь данных линий, а именно: нормальном, послеаварийном и планово-ремонтном. Защчта линий с двусторонним питанием, которые связывают с мощными электрическими системами отдельные местные электростанции, в том числе рассредоточенные источники генерации, местные системь и рассредоточенные источники генерации между собой, должны удовлетворять общзим требованиям обеспечения необходимой чувствительности, селективности действия при различных видах повреждений. Трудности в обеспечении необходимой чувствительности при использовании максимальных токовых защит на таких линиях связанные с малым уровнем токов короткого замыкания от рассредоточенных источников генерации $u$ местных электрических систем. Приведены особенности выполнения релейной зашиты при резервировании электроснабжения потребителей с использованием рассредоточенных источников генерачии. Максимальный рабочий ток линии, который потребляется с электрической системы, в 2 - 3 раза превышает номинальный ток, который определяется мощуностью генераторов рассредоточенных источников генерачии. При этом токи короткого замыкания от генераторов маломощуных рассредоточенных источников генерации оказываются соразмерныли с максимальныли рабочими токами линии. На линиях с двусторонним питанием, которые связывают с мощной электрической системой местные системы и рассредоточенные источники генерации между собой, максимальные токовые направленные защчтыл обеспечивают селективность и являются основныли видами защчит таких линий.

Ключевые слова: электроснабжение, релейная защита, реклоузеры, секционолайзеры, рассредоточеные источники генерации, короткое замыкание, секционирование, селективность 


\title{
IMPROVEMENT OF WAYS OF IMPLEMENTATION OF PROTECTING LINES OF COMMUNICATION WITH SUBSTATIONS OF DISTRIBUTED GENERATION SOURCES
}

\author{
A. Omelchuk, S. Voloshyn, O. Tarasjuk
}

\begin{abstract}
The article deals with the problems of using relay protection of power lines. Attention is paid to the peculiarities of the operation of protection under different modes of operation of these lines, namely: normal, post-accident and scheduled repair. The protection of two-sided power lines that connect individual local power plants to powerful electrical systems, including dispersed generation sources, local systems, and dispersed generation sources, must meet the general requirements of providing the required sensitivity, selectivity for various types of damage. Difficulties in providing the required sensitivity when using maximum current protections on such lines are associated with low levels of short-circuit currents from dispersed generation sources and local electrical systems. The features of the relay protection performance in redundant power supply of consumers using dispersed generation sources are given. The maximum operating current of the line consumed from the electrical system is $2-3$ times the rated current, which is determined by the power of the generators of the dispersed sources of generation. In this case, the short-circuit currents from the lowpower generators of the dispersed sources of generation are proportional to the maximum operating currents of the line. On double-sided power lines that connect local systems and dispersed power sources to a high-power electrical system, maximum current directional protection provides selectivity and are the main types of protection for such lines.
\end{abstract}

Key words: power supply, relay protection, reclosers, sectionalizers, distributed sources of generation, short circuit, sectioning, selectivity 